Bangladesh J. Bot. 50(3): 729-736, 2021 (September) SpecialＤOI: https://doi.org/10.3329/bjb.v50i5.56423

\title{
EFFECTS OF DIFFERENT FERTILIZATION MEASURES ON CORN YIELD AND SOIL NITROGEN LEVEL IN HOLLOW VILLAGE ON THE LOESS PLATEAU
}

\author{
Lei Shi ${ }^{1,2,3}$, Zhong Zheng LiU ${ }^{1}$, Liangyan YANG ${ }^{1}$ and Wangtao Fan ${ }^{1}$ * \\ Shaanxi Provincial Land Engineering Construction Group Co. Ltd., \\ Xi'an, Shaanxi, 710075, China
}

Keywords: Hollow village reclamation, Corn yield, Fertilization measures, Soil nitrogen

\begin{abstract}
Problems of poor soil structure and nutrient deficiency in the reclamation of abandoned homesteads, and improvement of the soil condition after land reclamation to arable land and rapidly resume agricultural production were investigated. Organic fertilizers, curing agent and fly ash as amendment materials were selected. A plot test with seven different return materials in order to obtain the effects of different amendment materials on nutrient improvement in the reclamation of abandoned homestead soils in loess areas was conducted. After 3 years of maize crop cultivation, soil samples were collected and analyzed for total soil nitrogen content under different treatments. The results showed that the maize yield in each plot showed different additives contributed to the increase in maize yield to different degrees, while the addition of organic fertilizer had a more significant effect on the increase in yield. In the treatment of the experimental plots with the addition of curing agent + organic fertilizer, there was a significant effect on the enhancement of the content of total nitrogen in the soil tillage layer after three years of maize cultivation. The total $\mathrm{N}$ content of the surface soil $(0 \sim 15 \mathrm{~cm})$ increased from 0.32 to $0.64 \mathrm{~g} / \mathrm{kg}$, and that of the soil from $15 \sim 30 \mathrm{~cm}$ increased from 0.31 to $0.66 \mathrm{~g} / \mathrm{kg}$. The total $\mathrm{N}$ content of the soil from $0 \sim 60 \mathrm{~cm}$ showed an increasing trend year by year, but the increase was gradually reduced. The total nitrogen content of soil in the depth of 60 105 $\mathrm{cm}$ showed a decreasing trend year by year. In the remediation of hollow villages in loess plateau, the compound application of organic fertilizer and ripening agent can significantly improve the soil nutrient content, condition of farmland and increase in maize yield, which is the most suitable material for field return in the remediation of hollow villages in loess plateau, and is of great significance to improve the quality of field return in the remediation of hollow villages.
\end{abstract}

\section{Introduction}

With the rapid development of social economy, farmers occupy farmland to build houses in the vast rural areas to promote the construction further of new countryside (Liu et al. 2019). This situation led to the occupation of a large number of high-yield farmland and leaving a large number of old homesteads and houses idle, forming an uninhabited hollow village (Fan et al. 2018, He et al. 2010). With the increase of area rural construction in cultivated land is gradually increasing, and the contradiction between protecting cultivated land and ensuring people's livelihood become increasingly prominent. This situation ultimately affected the implementation of China's basic national policy of protecting cultivated land and realizing food security (Zhong et al. 2010, Li et al. 2016). According to the data of the second land survey in Shaanxi Province, the total construction land area of urban and rural villages is 64 million hectare, of which the rural residential land accounts for $73.2 \%$, and the area available for reclamation is nearly 8 million hectare, accounting for $12.1 \%$ of the rural residential land. The lack of overall planning for rural

*Author for correspondence: <562176930@qq.com> ${ }^{1}$ Key Laboratory of Degraded and Unused Land Consolidation Engineering, the Ministry of Land and Resources, Xi' an, Shaanxi, 710075, China. ${ }^{2}$ Institute of Land Engineering and Technology, Shaanxi Provincial Land Engineering Construction Group Co. Ltd., Xi' an, Shaanxi, 710075, China. ${ }^{3}$ Shaanxi Provincial Land Consolidation Engineering Technology Research Center, Xi' an, Shaanxi, 710075, China. 
residential land utilization or development led to low efficiency in use of land. Therefore, the development of rural hollow village waste became essential to alleviate the tension between people and land, which may play a very important role in the intensive and efficient use of land (Shade and Stephen 2014). Hollow village homestead reclamation is an innovative means to balance the occupation and compensation of cultivated land (Wang et al. 2011).

However, during the implementation of the project, the original topography and landform was overturned, and the raw soil of the parent material layer of the original cultivated land was mixed with the mature soil on the surface, resulting in the reduction of crop yield and even to the inability to grow crops (Denef et al. 2013). The application of organic fertilizer is the main way to improve the soil quality after homestead Reclamation (He et al. 2013, Cheng et al. 2019). According to the soil characteristics of the hollow village reclamation area in the original loess plateau area, organic fertilizer, fly ash and soil curing agent were selected as improvement materials. The plot experiment was conducted to study the effect of different improvement materials on the nitrogen increase of reclaimed soil, so as to find the best improvement material for improving soil fertility, which was the residential land of hollow village in this area.

\section{Materials and Methods}

The experimental plots are located in Fuping County, Weinan City, Shaanxi Province. This area belongs to the semi-arid climate zone of inland warm temperate zone. The climate characteristics are abundant sunlight, mild climate and four distinct seasons. The terrain is high in the north and low in the south, with mountains and rivers alternating with each other, and the central plains are undulating. The altitude is $380 \sim 1439 \mathrm{~m}$, with an average altitude of $900 \mathrm{~m}$, annual average precipitation of $473.0 \mathrm{~mm}$, annual evaporation of $1000 \sim 1300 \mathrm{~mm}$, frost free period of $225 \mathrm{~d}$, and annual average temperature of $13.4^{\circ} \mathrm{C}$.

The raw soil collected from Yuzihe village of Chengcheng County was used to cover the surface of the experimental plots. For Hollow village reclamation and return material test plots, 2 groups of replications were set up, each group containing 7 plots, each plot area was of $2 \times 2 \mathrm{~m}$. Before the experiment, the soil was tested in the $0-20 \mathrm{~cm}$ layer and the results were $4.3 \mathrm{~g} / \mathrm{kg}$ of organic matter, $2.1 \mathrm{mg} / \mathrm{kg}$ of effective phosphorus, $70.4 \mathrm{mg} / \mathrm{kg}$ of fast-acting potassium and 0.16 $\mathrm{g} / \mathrm{kg}$ of total nitrogen.

In the present study, organic fertilizer, curing agent and fly ash were used as improved materials, and the treatment without adding any improved materials was used as a control. There were seven treatments in total (Table 1), and each treatment was repeated 3 times (Wu et al. 2011). In the plot layout, the tillage layer was stripped $(0-30 \mathrm{~cm})$, and then filled with the raw soil collected from the hollow village homestead reclamation area, the filling amount was the same as the stripping amount; the plot was separated by cement wall with a depth of $40 \mathrm{~cm}(10 \mathrm{~cm}$ higher than the ground); the two groups of repetition interval were $0.5 \mathrm{~m}$; the experimental plot was irrigated by sprinkler irrigation. According to different combination schemes, each plot was designed with 2 replicates and random block design, with a total of 14 plots (Zheng et al. 2013).

Corn was planted in mid-June and harvested at the end of September. The planting row spacing was $50 \mathrm{~cm}$ and the plant spacing was $15 \mathrm{~cm}$. Plants were planted in 4 rows in each plot and each row was planted with 13 beads. When the corn matures, the yield was measured after harvesting.

Three sampling points were randomly selected in each plot to test soil samples, and each sample point was taken from 0 15, 15 30, 30 45, 45 60, 60 75, 75 90 and 90 105 cm soil layer 
The soil samples were naturally air-dried, ground, and passed through a $0.149 \mathrm{~mm}$ sieve to determine the total nitrogen content of the soil (Meng et al. 2011).

Table 1. Test design.

\begin{tabular}{c|l|l}
\hline $\begin{array}{c}\text { Test plot } \\
\text { number }\end{array}$ & Treatments & Application rate $\left(\mathrm{t} / \mathrm{hm}^{2}\right)$ \\
\hline 1 & Curing agent (Ferrous sulfate) (F) & 0.6 \\
2 & Organic Fertilizer (Chicken manure) (S) & 30 \\
3 & Fly ash (C) & 45 \\
4 & Curing agent + Organic Fertilizer (F+S) & $0.6+30$ \\
5 & Organic Fertilizer + Fly ash (S +C) & $30+45$ \\
6 & Curing agent + Fly ash (F + C) & $0.6+45$ \\
7 & No fertilization measures (CK) & 0 \\
\hline
\end{tabular}

Ten ears of corn were selected from each plot to test the species to analyze the yield structure, and finally the yield was converted to the standard value of $14 \%$ moisture content.

An additional work was carried out with laboratory analyzed soil samples collected from experimental field. Total nitrogen was determined by the $\mathrm{K}_{2} \mathrm{Cr}_{2} \mathrm{O}_{7}-\mathrm{H}_{2} \mathrm{SO}_{4}$ digestion method with a Kjeldahl nitrogen tester (Yang et al. 2011).

\section{Results and Discussion}

Results of corn output of the experimental plots for three years revealed that the corn output of each plot has increased (Fig. 1). In 2017, the output of No. 2 experimental plot (S) was significantly higher than others, reaching $12000 \mathrm{~kg} / \mathrm{hm}^{2}$. Compared with the No. 7 plot of the blank control experiment, the yield increased by about $60.4 \%$, indicating that organic fertilizer can promote the growth and yield of corn. However, the yield of No. 4 experimental plot $(\mathrm{F}+\mathrm{S})$ was lower than No. 7, indicating that the addition of curing agent inhibited the growth of corn. The output of No. 1, No. 5 is almost the same as that of No. 7.

With the passage of time, the output of the No. 4 experimental plot $(\mathrm{F}+\mathrm{S})$ in 2018 has increased significantly, indicating that the soil curing agent has promoted soil maturation after one year of action, thereby providing more suitable conditions for the growth and maturity of corn. The output of No. 2 experimental plot (S) also increased in 2018, and the output was still the highest, which was significantly higher than that of other experimental plots. As can be seen from the figure, the output of each experimental plot in 2018 showed an increasing trend.

In 2019, the output of plots 1, 2, and 3 reached almost the same level, and the yields of plots 4,5 , and 6 were relatively close. Although plot 7 had an increase, the increase was insignificant. It can be seen from the corn output of each plot that different additives have different degrees of contribution to the increase of corn yield, and the addition of organic fertilizer is of great help to the increase in yield.

After the test plot was covered with soil, since the collected land for reclamation of the homestead was raw soil, the total nitrogen content was low. From the figure, it can be seen that the content was between 0.3 and $0.5 \mathrm{~g} / \mathrm{kg}$. After 3 years of cultivation, the total nitrogen content of the soil at different depths under different fertilization treatments showed different changes. 


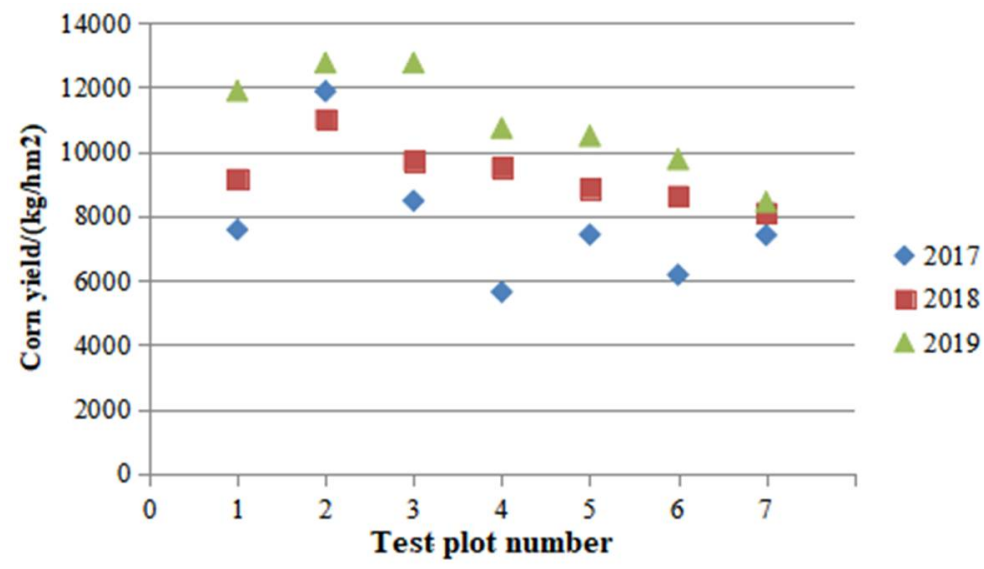

Fig.1 Corn production in each experimental plot 2017-2019.

As can be seen from Fig. 2 that the total nitrogen content of soils at different depths in the experimental plots with curing agents increased year by year. The increment of the cultivated layer $(0 \sim 30 \mathrm{~cm})$ was most obvious, and the increment reached $0.6 \mathrm{~g} / \mathrm{kg}$. From the spatial scale, the effect of adding curing agents on the total nitrogen content of soil profiles at different depths is positive, and the content of each layer tends to be the same. It can be seen that the curing agent had a more obvious effect on the reclaimed soil.

As can be seen from Fig. 3, the total nitrogen content in the top soil of the experimental plot with organic fertilizer changed little during three-years of farming. The soil with a depth of 15 30 $\mathrm{cm}$ had a significant increase in total nitrogen content, from 0.41 to $0.65 \mathrm{~g} / \mathrm{kg}$. The total nitrogen content of other soils at different depths showed a trend of increasing year by year, but the increase was small. From a spatial scale, the effect of adding organic fertilizer on the total nitrogen content of soil profiles at different depths was positive. It can be seen from this that organic fertilizer has a general effect on the maturation of the reclaimed soil, and had more obvious effect on the nitrogen content of the shallow plough soil.

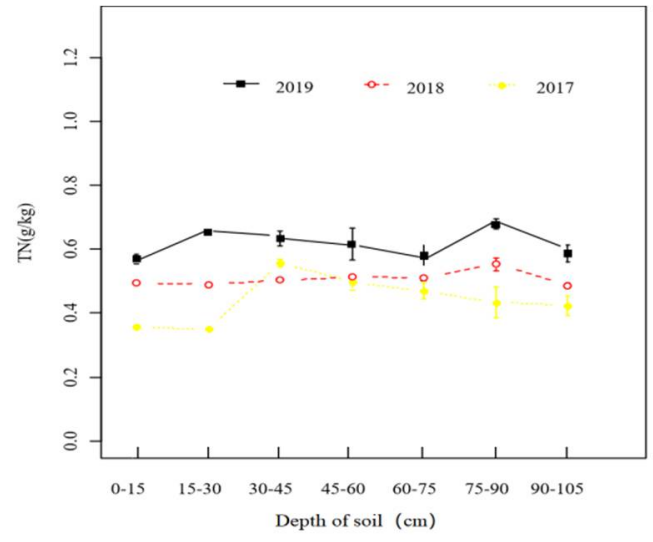

Fig. 2. Effects of adding curing agent on total nitrogen content at different depths of soil.

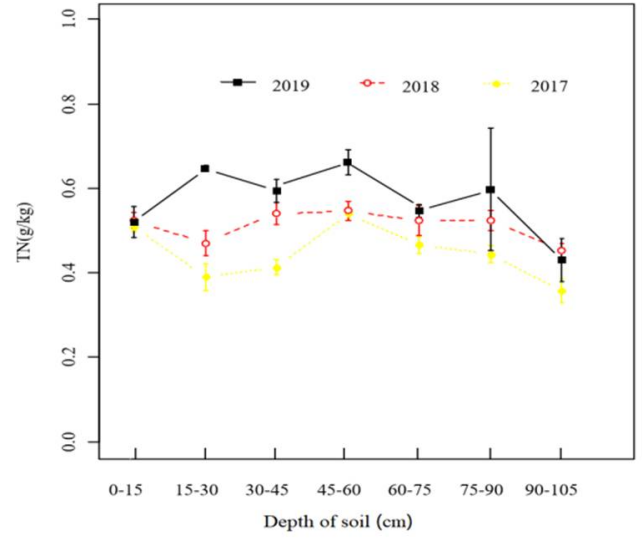

Fig. 3. Effects of adding organic fertilizer on total nitrogen content at different depths. 
The total nitrogen content in the topsoil of the experimental area added with fly ash changed little during three-years of farming (Fig. 4). The soil with a depth of $15 \sim 30 \mathrm{~cm}$ had a significant increase in total nitrogen content, from 0.37 to $0.62 \mathrm{~g} / \mathrm{kg}$. In the soil layer with a depth of 45 60 $\mathrm{cm}$, the total nitrogen content changed little. The total nitrogen content of other soils at different depths showed a trend of increasing year by year, and the increase rate increased with the increase of soil depth. From the spatial scale, the effect of adding fly ash on the total nitrogen content of soil profiles at different depths was positive except for the depths of $0 \sim 15$ and $45 \sim 60 \mathrm{~cm}$. The fly ash had a general effect on the maturation of the reclaimed soil, and had a more positive effect on the nitrogen content of the shallow plough soil.

The total nitrogen content of topsoil $(0 \sim 15 \mathrm{~cm})$ soil in the experimental plot with the addition of curing agent + organic fertilizer increased significantly from 0.33 to $0.64 \mathrm{~g} / \mathrm{kg}$ after three years of growing corn (Fig. 5). It was $0.64 \mathrm{~g} / \mathrm{kg}$. The soil with a depth of $15 \sim 30 \mathrm{~cm}$ had a significant increase in total nitrogen content, from 0.31 to $0.66 \mathrm{~g} / \mathrm{kg}$. The total nitrogen content of the soil with a depth from 0 to $60 \mathrm{~cm}$ showed an increasing trend year by year, but the rate of increase gradually decreases with its increase of depth from 60 to $105 \mathrm{~cm}$.

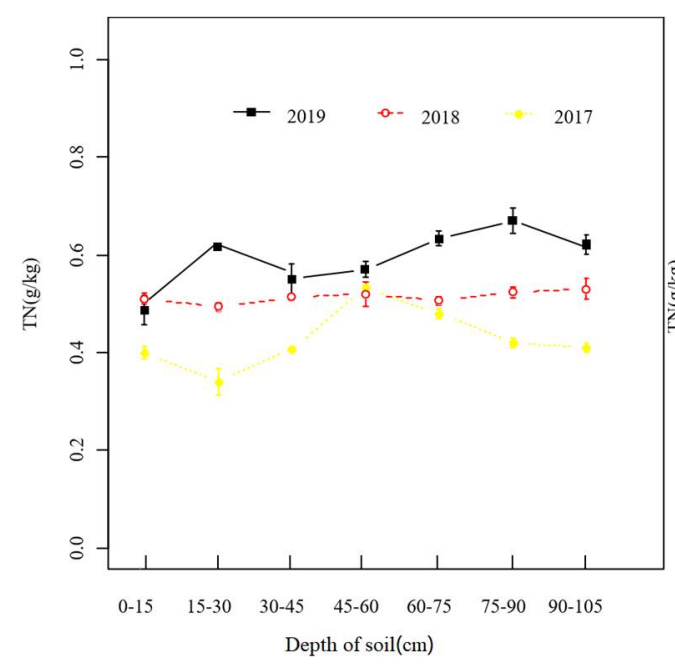

Fig. 4. Effects of adding fly ash on total nitrogen content organic of soil at different depths.

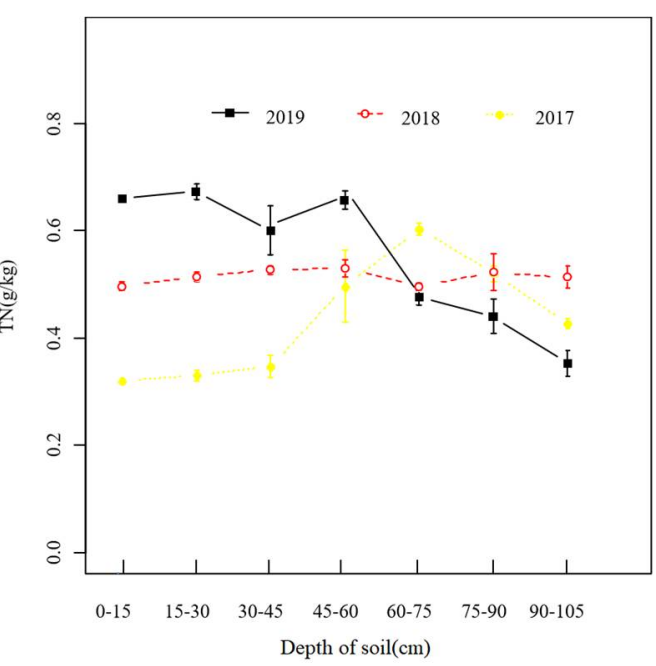

Fig. 5. Effects of adding curing agent and fertilizer on soil at different depths.

In the experimental area where fly ash and organic fertilizer were added, the total nitrogen content of the top soil increased significantly, from 0.31 to $0.63 \mathrm{~g} / \mathrm{kg}$ (Fig. 6). The total nitrogen content of other soils at different depths showed a trend of increasing year by year, and the increase rate increased with the increase of soil depth into $60-75 \mathrm{~cm}$. From the spatial scale, the effect of adding $\mathrm{S}+\mathrm{C}$ on the total nitrogen content of soil profiles at different depths was positive except for the depth of 30 45 $\mathrm{cm}$. The highest maturation effect on the surface raw soil of the reclaimed soil was $0-15 \mathrm{~cm}$ in the year 2019 .

The total nitrogen content of the topsoil $(0 \sim 15 \mathrm{~cm})$ soil increased from 0.36 to $0.58 \mathrm{~g} / \mathrm{kg}$ in the experimental plot with the addition of curing agent and fly ash $(\mathrm{F}+\mathrm{C})$. The soil at the depth of $15 \sim 30 \mathrm{~cm}$ shared the significant increase in total nitrogen content, from 0.41 to $0.89 \mathrm{~g} / \mathrm{kg}$. Then it started to decrease up to the depth of $60 \sim 75 \mathrm{~cm}$ suddenly year by year in 2019. In the year 2017 and 2018 increase of nitrogen level did not show any significant difference. 
From the above result it can be seen that the addition of improved materials can significantly increase the total nitrogen content of the soil, and the treatment of adding the curing agent + fly ash $(\mathrm{F}+\mathrm{C})$ showed the best effect on the improvement of the total nitrogen of the soil in the cultivated layer $(0-30 \mathrm{~cm})$ (Fig. 7$)$.

The total nitrogen content of the soil in the cultivated layer in the experimental plot of the control group did not show much difference in three consequent years. The changes were very insignificant (Fig. 8).

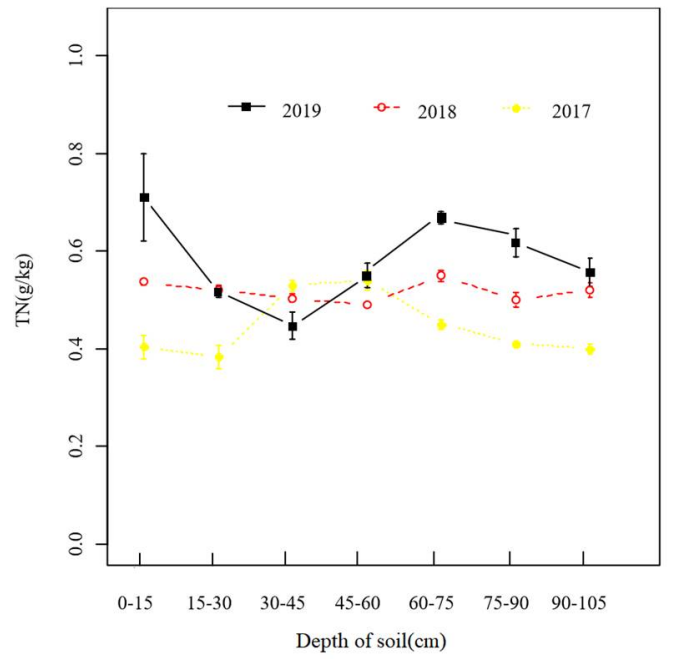

Fig. 6. Effects of adding fly ash and organic fertilizer on total nitrogen content in different depths of soil.

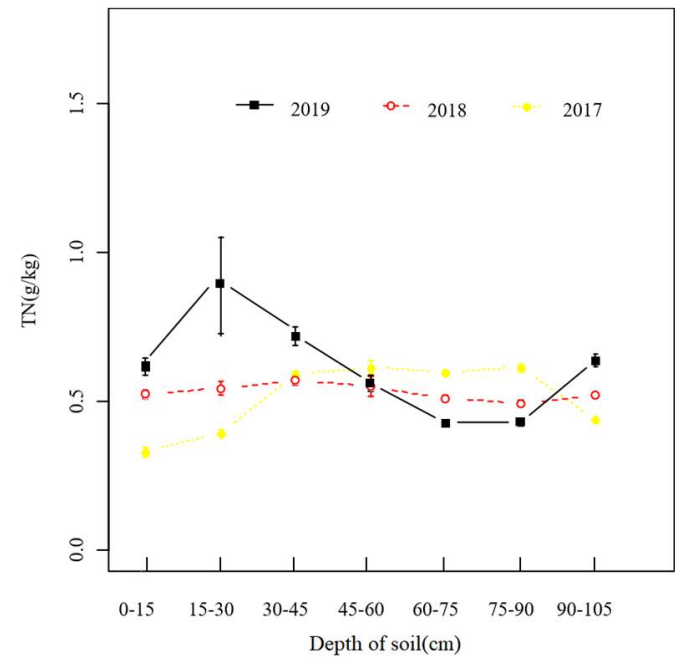

Fig. 7. Effects of adding curing agent and fly ash on total nitrogen content at different depths of soil.

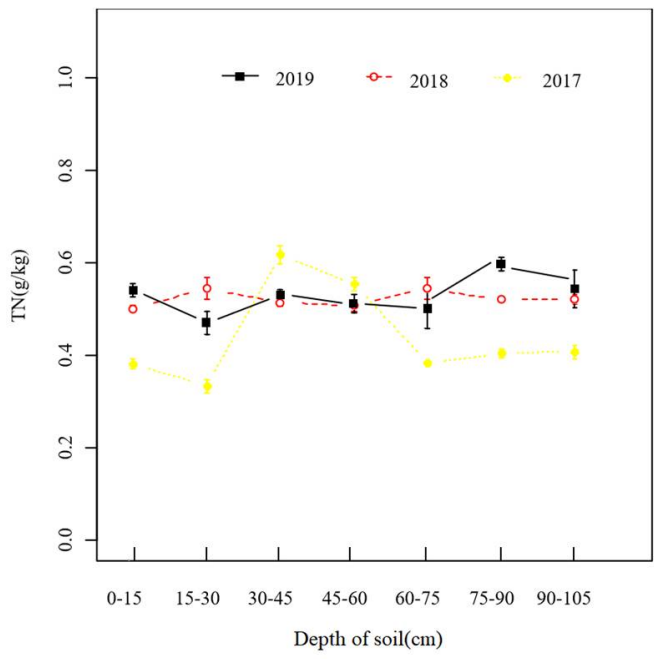

Fig. 8. Effects of no fertilization measures (control) on soil total nitrogen content at different depths of soil. 
The corn output of each plot with different additives has different degrees of contribution to the increase of corn yield, and the addition of organic fertilizer is great help in the increase of yield.

Soil organic matter, total nitrogen, available phosphorus, and available potassium content are important indicators that reflect soil fertility, and are also important nutrients necessary for crop growth. In the present study only nitrogen content of the soil was measured using three different materials, organic fertilizer, curing agent and fly ash which were selected to improve the soil for homestead reclamation. It was found that after adding organic fertilizer, curing agent and fly ash for three years of growing corn has a certain effect on the improvement of soil nutrients in the reclaimed soil of the homestead. The treatment of curing agent + fly ash $(F+C)$ showed the highest increase $(0.89 \mathrm{~g} / \mathrm{kg})$ in the total nitrogen content of the cultivated soil. When compared with the raw soil in the early stages of reclamation, the total nitrogen content of the soil has also significantly improved after three consecutive years of planting corn.

Results showed more than $70 \%$ of the soil in the reclaimed land was directly flattened by the wall of the homestead, and there was a serious lack of organic matter and available phosphorus in the soil. The reclaimed land in the hilly area showed that its organic matter, available phosphorus, available potassium and other nutrients are all low, and the soil structure is poor. Improvement and fertilization of the reclaimed soil at the homestead will gradually increase its productivity, but different fertilization measures have different effects on different regions and different soil types (Qian et al. 2003, Li et al. 2010, Wang et al. 2012).

The impact of different improved materials on the nutrient content of the homestead reclamation soil was studied (Rong et al. 2012, Zhang et al. 2008). In the follow-up, a comprehensive analysis will be carried out to study other physical, chemical, and biological properties to explore the more suitable land reclamation land management process and increased fertility in the loess area.

\section{Acknowledgements}

The Project was supported by the projects of "Technology Innovation Leading Program of Shaanxi (Program No.2021CGBX-03)", Shaanxi Provincial Land Engineering Construction Group (DJNY2020-30, DJNY2021-33).

\section{References}

Cheng M, Xie WY, Yang ZX and Zhou HP 2019. Effects of long-term straw return on corn yield, soil nutrient contents and enzyme activities in dryland of the loess plateau, China. Chinese J. Eco-Agricul. 2019(10): 1528-1536.

Denef K, Galdo ID, Venturi A and Cotrufo MF 2013. Assessment of soil c and n stocks and fractions across 11 european soils under varying land uses. Open J. Soil Sci. 3(7): 297-313.

Fan L, Li YH and Xu B 2018. Effect of different plant species and fertilization conditions on mineral nitrogen in gully region of loess plateau. Bull. Soil Water Conserv. 223(02):121-127.

He X, Hao M and Chen L 2013. Effects of fertilization and precipitation on winter wheat yield and nitrogen use efficiency on the Loess Plateau. J. Food Agri. Environ. 11(3): 1227-1232.

He XY, Hao MD, Li HC and Cai ZF 2010. Effects of different fertilization on yield of wheat and water and fertilizer use efficiency in the loess plateau. Plant Nutri. Fert. Sci. 50(2): 137-154.

Li FL, Hao MD, Yang X and Xu JJ 2010. Effects of fertilization on soil water and winter wheat yield in dry land of loess plateau. J. Triticeae Crops 30(1): 154-157.

Li S, Zhang S, Pu YL, Xu T, Jia X and Gong Y 2016. Dynamics of soil labile organic carbon fractions and Ccycle enzyme activities under straw mulch in Chengdu Plain. Soil Tillage Res. 155: 289-297. 
Liu ZX, Deng LJ, Zhou W, Chen LD and Zou GJ 2019. Evaluation of effects of organic materials on soil fertilization of reclaimed homestead. Soils 51(4): 672-681.

Meng XY, Wang ZH, Yang N, Yang R, Zhang ZL and Zhao HB 2011. Effects of soil moisture before sowing and phosphorus fertilization on winter wheat yield, water and fertilizer use efficiencies on weibei tableland of the loess plateau. Plant Nutri. Fert. Sci. 17(5):1083-1090.

Qian LY, Bandaranayake W, Parton WJ, Mecham B, Harivandi MA and Mosier AR 2003. Long-term effects of clipping and nitrogen management in turfgrass on soil organic carbon and nitrogen dynamics. $\mathrm{J}$ Environ. Quality 32(5): 1694.

Rong JR., Li CH, Wang YG, Tang LS and Chen XM 2012. Effect of long-term fertilization on soil organic carbon and soil inorganic carbon in oasis cropland. Arid Zone Res. 29(4): 592-597.

Shade J and Stephen N 2014. Storage of total and labile soil carbon fractions under different land-use types: A Laboratory Incubation Study. Soil Carbon. Springer International Publishing.

Wang KR, Pan WC, Li SK, Chen B, Xiao H and Wang FY 2011. monitoring models of the plant nitrogen content based on cotton canopy hyperspectral reflectance. Spectros. Spectral Anal. 31(7): 1868-1872.

Wang S, Wang X and Ouyang Z 2012. Effects of land use, climate, topography and soil properties on regional soil organic carbon and total nitrogen in the upstream watershed of miyun reservoir, north China. J. Environ. 24(003): 387-395.

Wu F, Dong M, Liu Y, Ma X, An L and Young JPW 2011. Effects of long-term fertilization on fungal community structure and glomalin-related soil protein in the loess plateau of China. Plant Soil 342(1-2): 233-247.

Yang X, Li P, Zhang S, Sun B and Chen X 2011. Long-term-fertilization effects on soil organic carbon, physical properties, and wheat yield of a loess soil. J. Plant Nutri. Soil Sci. 174(5): 775-784.

Zhang L, Ping Z, Liu Y, Ying Q, Yong J and Gao H 2008. Effect of long-term fertilization on organic carbon and nitrogen contents in a black soil of northeast China. Agricul. Journal (3).

Zhang Y, Liu YJ, Ni JP and Xie DT 2015. Effect of tree/mushrooms intercropping on "purple soil" labile organic carbon in the three gorges reservoir region. Acta Pratacultuae Sinica. 5: 53-65.

Zheng S, Hu J, Jiang X, Ji F, Zhang J, Yu Z and Lin X 2013. Long-term fertilization regimes influence fame profiles of microbial communities in an arable sandy loam soil in northern China. Pedobiol. 56(4-6), 179-183.

Zhong W, Gu T, Wang W, Zhang B, Lin X, Huang Q and W Shen 2010. The effects of mineral fertilizer and organic manure on soil microbial community and diversity. Plant Soil 326(s1-2), 523

(Manuscript received on 19 May, 2021; revised on 28 September, 2021) 